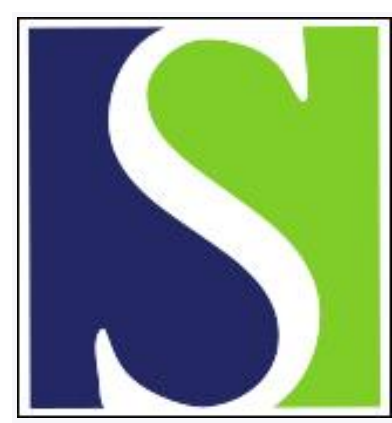

Scand J Work Environ Health 1991;17(6):369-379

https://doi.org/10.5271/sjweh.1691

Issue date: Dec 1991

Toxicology and occupational hazards of new materials and processes in metal surface treatment, powder metallurgy, technical ceramics, and fiber-reinforced plastics.

by Midtgard U, Jelnes JE

Affiliation: Department of Toxicology and Biology, National Institute of Occupational Health, Copenhagen, Denmark.

This article in PubMed: www.ncbi.nlm.nih.gov/pubmed/1788529

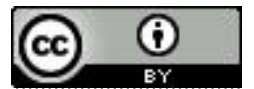




\title{
Toxicology and occupational hazards of new materials and processes in metal surface treatment, powder metallurgy, technical ceramics, and fiber-reinforced plastics
}

\author{
by Uffe Midtgård, DSc, ${ }^{1}$ Jens $E$ Jelnes, $\mathrm{DSc}^{1,2}$
}

\begin{abstract}
MIDTGÄRD U, JELNES JE. Toxicology and occupational hazards of new materials and processes in metal surface treatment, powder metallurgy, technical ceramics, and fiber-reinforced plastics. Scand $J$ Work Environ Health 1991;17:369-79. Many new materials and processes are about to find their way from the research laboratory into industry. The present paper describes some of these processes and provides an overview of possible occupational hazards and a list of chemicals used or produced in the processes. The technological areas that are considered are metal surface treatment (ion implantation, physical and chemical vapor deposition, plasma spraying), powder metallurgy, advanced technical ceramics, and fiberreinforced plastics.
\end{abstract}

Key terms: carbides, chemical vapor deposition, fibers, high-tech ceramics, ion implantation, nitrides, oxides, physical vapor deposition, plasma spray.

Technological advancement implies that new processes and materials are constantly being developed. This development involves several industries and scientific disciplines, and the research is often carried out as part of governmental programs. For example, some of the Nordic countries have encouraged research and development in new material technologies by allocating large sums of money for this field. As a result of such programs, several new technological processes are about to find their way from the research laboratory into more general use in industry.

It is the purpose of the present paper to provide an overview of the different kinds of materials and potential workplace hazards associated with some technologies which are more or less new. The technologies that are considered in this report are metal surface treatment, powder metallurgy, advanced technical ceramics, and fiber-reinforced plastics. These areas were chosen since they are about to have a major industrial breakthrough in the Nordic countries.

As an initial step in identifying the chemicals used or produced in the various processes and their potential workplace hazards, we have consulted handbooks, information booklets, and research proposals from various technology centers. Information has also been gathered from meetings and visits to some of the research centers.

In being engaged at an early stage, it is our hope that new hazards are foreseen so that serious occupa-

1 Department of Toxicology and Biology, National Institute of Occupational Health, Copenhagen, Denmark.

2 Present address: Department of Environmental Technology, Danish Technology Institute, Taastrup, Denmark.

Reprint requests to: Dr U Midtgård, Department of Toxicology and Biology, National Institute of Occupational Health, Lersø Parkallé 105, DK-2100 Copenhagen, Denmark. tional injuries can be prevented. Furthermore, we hope that designers, engineers, and industrial hygienists will be alerted to the new hazards that are inevitably coupled with new technologies.

\section{New materials}

Very often new processes and materials are introduced into the workplace before their impact on industrial hygiene is fully understood (1). In fact, scientists are able to create new materials and new chemicals at a much faster rate than the toxicologist can evaluate them. Consequently, many of the substances currently handled or produced in industrial processes are toxicologically unknown. This problem may be of limited concern to designers and research scientists, who are generally not subjected to serious or long-term exposure to hazardous agents. However, in large-scale industrial applications the risk of long-term exposure, and accidental overexposure, is ever present. Therefore, protection of the employees becomes very important, especially when one is dealing with substances that are toxicologically unknown.

New chemicals are by definition almost unknown, and the majority have never been subjected to adequate laboratory tests for biological effects before they are placed on the market. However, new materials are not necessarily synonymous with new chemicals. Very often new materials consist of well-known substances which are mixed or prepared in a manner which leads to a material with new and attractive properties. New materials emerge as a result of intense research and development, and they are characterized by a rapidly growing market. Furthermore, it is characteristic of many new materials that different compounds have been combined in a composite material with unique 
properties. In product design, this development means that there is a tendency towards a breakdown of the divisions between the traditional groups of materials such as metals, ceramics, and plastics. New materials as a concept varies both temporally and geographically. What is considered new in Scandinavia may have been used industrially for many years in other countries.

The different chemicals or substances encountered in the literature search on new materials have been listed in the appendix. The presence or absence of toxicological data was inferred from a check of all the chemicals against the Registry of Toxic Effects of Chemical Substances (2), and, for some of the chemicals and substances, a special search was performed in the data base TOXALL. Apparently, many of the chemicals are toxicologically unknown although they can hardly be considered new. In the following discussion, some of these chemicals and the technologies using them will be considered in more detail.

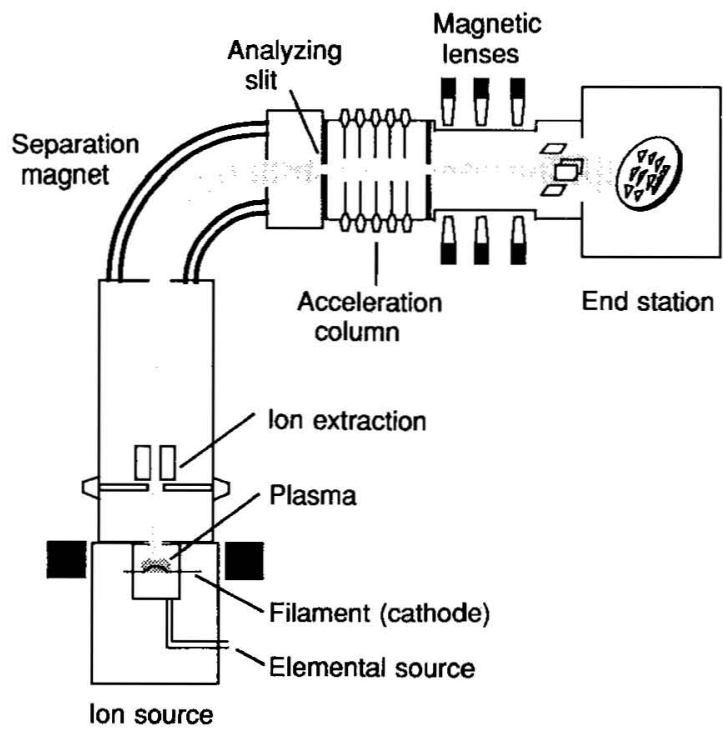

Figure 1. Typical device for ion implantation. Adapted from reference 3 .

\section{New surface treatment techniques}

Metal surface treatment comprises a variety of methods in which a metallic substrate is coated with another material either for decorative purposes or for the production of corrosion-resistant or wear-resistant objects. Metal surface treatment may also be performed to reduce friction or improve the adhesion of a following layer. It includes well-known methods such as electroplating and electroless plating, but during the last couple of decades more sophisticated techniques have come into use, especially in the manufacture of wearresistant tools. Numerous compounds are currently being used as coating materials (see the appendix), but the refractory coating of wear-resistant tools usually consists of either carbides, nitrides, or oxides.

In some processes (eg, electroplating and physical vapor deposition), the material is simply deposited directly on the substrate, and in others (eg, ion implantation), a surface layer consisting of both the substrate and the added material is produced.

It is not the purpose of the present survey to review the occupational hazards of all techniques for metal surface treatment. This contribution will be restricted to the occupational hazards of ion implantation, chemical and physical vapor deposition, melt spraying, and the toxicity of some of the compounds being produced or used in these processes.

\section{Ion implantation}

General aspects. In the ion implantation technique, the surface of an object is bombarded with high-energy ions which penetrate into the material to depths of up to $0.5 \mu \mathrm{m}$. Unlike other metal surface treatment processes, ion implantation does not produce dimensional changes in the object, and the protective layer does not break off. Furthermore, ion implantation is a low-temperature process that allows treatment of practically all materials - even plastics (3).

Ions from a gaseous material are produced in the ion source and are accelerated towards a separation magnet (figure 1). The beam then passes into a column where the ions are accelerated through an electrical

Table 1. Occupational hazards associated with different techniques in metal surface treatment.

\begin{tabular}{lll}
\hline Technique & Hazard & Preventive measure \\
\hline Ion implantation & High voltage (electrical shock) & Grounding procedures \\
& $\begin{array}{l}\text { lonizing radiation } \\
\text { Toxic gases and liquids } \\
\text { Electromagnetic fields }\end{array}$ & $\begin{array}{l}\text { Shielding } \\
\text { Exhaust ventilation }\end{array}$ \\
& Shielding \\
Physical vapor deposition & Solvent cleaning of objects & Exhaust ventilation \\
& High voltage & Shielding, grounding \\
(Dust from cleaning of reaction chamber) & Dust control \\
Chemical vapor deposition & Irritative compounds (eg, titanium tetrachloride) & Exhaust ventilation \\
& Toxic gases (eg, carbon monoxide) & Exhaust ventilation \\
& Explosive gases (hydrogen + air) & Exhaust ventilation \\
Plasma spray & Noise & Acoustical protection \\
& Toxic fumes & Exhaust ventilation, air-line ventilator \\
& Ultraviolet light & Shielding, gloves \\
\hline
\end{tabular}


potential of up to $150 \mathrm{kV}$. The ion beam is then focused on the target, which is placed on a computer-controlled manipulator in the end station. For producing wear-resistant tools, the ions $\left(\mathrm{N}^{+}, \mathrm{Ti}^{+}, \mathrm{Cr}^{+}, \mathrm{B}^{+}\right)$are produced from nitrogen, titanium tetrachloride, chromium (VI) dioxychloride, and boron trichloride. In the semiconductor industry ion implantation is used to produce arsenic- or phosphide-doped silicon, and the dopant ions are generated from arsine and phosphine (4).

Hazards. The occupational hazards associated with ion implantation are summarized in table 1 . The personnel operating the ion implanter are, first of all, at risk from contact with the high-voltage unit and exposure to ionizing radiation. To avoid accidents, access to the high-voltage unit should be prevented by enclosure of this part of the equipment during operation, and regular or emergency shut-down of the ion implanter must include grounding procedures. Ionizing radiation should be measured after an implanter has been installed, and lead shielding should be applied if necessary. However, results of badge dosimetry monitoring of personnel operating ion implanters indicate that serious exposure to ionizing radiation normally does not occur (4).

Some of the chemicals used in the process of ion implantation in the semiconductor industry are very toxic (eg, arsine and phosphine). Workplace monitoring has shown that workers are continuously exposed to lowlevel concentrations of the dopants (4). However, the occupational exposure limits were not exceeded. Apparently, the exhaust ventilation near the ion source and vacuum pumping system provides sufficient protection of the personnel.

Boron trichloride and titanium tetrachloride, which are used for producing refractory coatings, are strongly irritant, and chromium (VI) dioxychloride contains hexavalent chromium, which is carcinogenic and allergenic. Although these compounds are used in very small amounts, they should be handled with care, and it is recommended that a ventilated face mask and gloves be used as protection against accidental leaks during the change of the gas cartridges.

The surface layer of the final ion-implanted product constitutes only a very small fraction of the entire product, and after-treatment is generally not necessary. Therefore, it is believed that the added material in the final product does not present any health risks.

\section{Physical vapor deposition}

General aspects. Physical vapor deposition includes several coating processes (eg, evaporation, ion plating, sputtering) in which an object is coated with a thin film in vacuum. Briefly, the material to be deposited is evaporated by resistance heating or bombardment with electrons or argon, after which it is transferred to the object where it creates a thin surface film. In ion plating, the ionized evaporant is transferred to the object by means of an electrical potential, but the potential is considerably lower $(<7 \mathrm{kV})$ than in ion implantation and the ions do not penetrate the surface of the object $(5,6)$.

The physical vapor deposition process is advantageous in that the temperature is considerably lower than in chemical vapor deposition. However, the surface coatings produced by physical vapor deposition are less resistant than those made with chemical vapor deposition, and the object must be completely free from dust and grease to secure a good result.

Hazards. The pretreatment of objects with solvent cleaning probably constitutes the most serious health risk in physical vapor deposition (table 1), and appropriate exhaust ventilation must be associated with this part of the system. In large-scale industrial use of the physical vapor deposition process, the equipment needed for cleaning objects is usually more expensive and voluminous than the physical vapor deposition apparatus.

The materials that can be deposited as films by the physical vapor deposition processes include metals, alloys, oxides, carbides, and nitrides. For many of the compounds, there is practically no toxicological data (eg, chromium carbide, iron carbide, titanium nitride), and it is therefore not clear whether they constitute an occupational hazard to the worker or consumer. Deposition of refractory coatings inside the reaction chamber may sometimes require cleaning by sand blasting. During this process dust is released to the work environment with the risk of inhalation.

\section{Chemical vapor deposition}

General aspects. In chemical vapor deposition, a surface coating is produced at high temperatures (500$1100^{\circ} \mathrm{C}$ ) by means of a chemical reaction between gaseous reactants and the substrate. Due to the high temperatures needed in the process, suitable substrates are restricted to metals and alloys with high melting points. However, in plasma-assisted chemical vapor deposition, a low substrate temperature can be used due to microwave or electrical-discharge plasma activation. The chemical vapor deposition processes are used particularly for producing wear-resistant coatings, but optical films and semiconductors may also be produced (6).

Wear-resistant coatings consisting of nitrides are produced by the process of bubbling hydrogen and nitrogen through liquid chlorides (eg, titanium tetrachloride or vanadium tetrachloride) and then passing the gas mixture over the objects in the reaction furnace (figure 2). Carbon nitride coatings are produced through the addition of methane (or carbon monoxide) to the reaction gas $(7,8)$. 


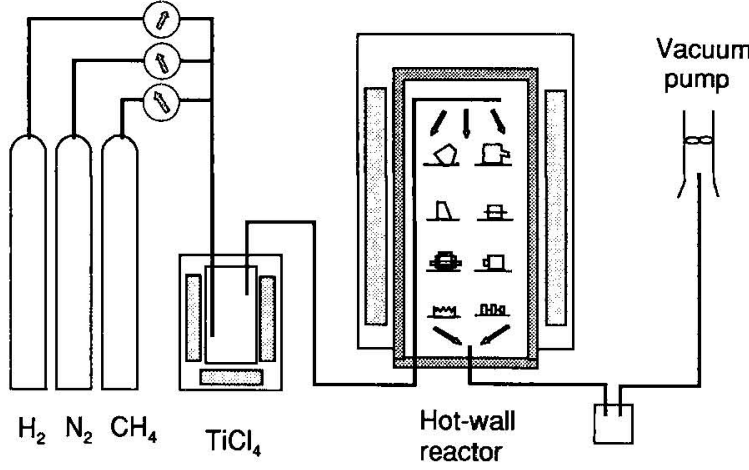

Figure 2. Technique for producing a titanium nitride coating by chemical vapor deposition. Adapted from reference 8 . $\left(\mathrm{H}_{2}=\right.$ hydrogen, $\mathrm{N}_{2}=$ nitrogen, $\mathrm{CH}_{4}=$ methane, $\mathrm{TiCl}_{4}=$ titanium tetrachloride)

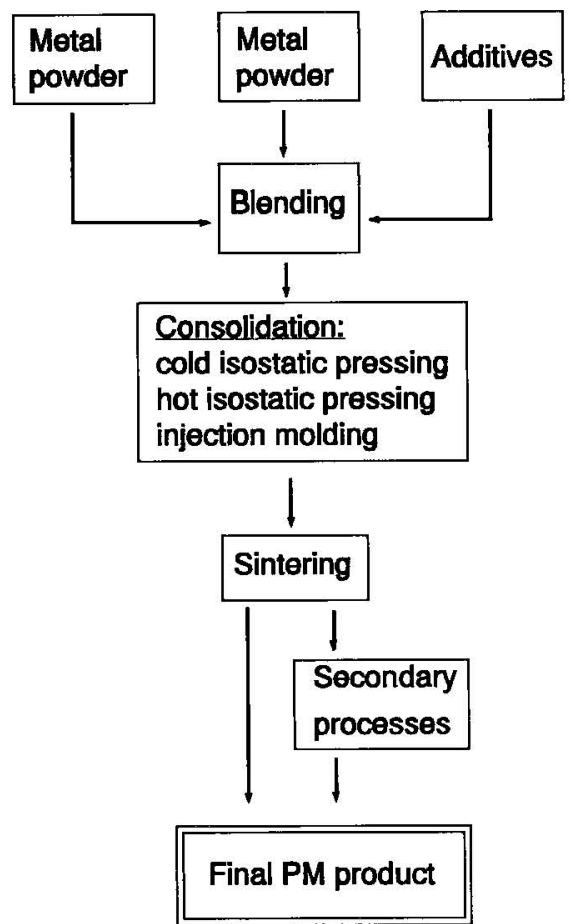

Figure 3. Main steps in manufacturing powder metallurgy products. Adapted from reference 9 .

Hazards. Several hazardous chemicals are used in chemical vapor deposition (table 1). For example, carbon monoxide has a high acute toxicity by inhalation, and hydrogen mixed with air is explosive. Exhaust from the reaction furnace to the open environment is therefore needed, and installation of carbon monoxide sensors in the room is recommended. In addition, the furnace should be ventilated with nitrogen before being opened. Titanium tetrachloride or vanadium tet- rachloride are strongly irritant, as is hydrochloric acid, which is produced in the process.

\section{Plasma spraying}

General aspects. In plasma spraying a gas is directed through a direct-current arc, which results in a hightemperature plasma that expands rapidly and is capable of melting any material. The material used for coating is fed as a powder into the plasma and is ejected at high speeds towards the object. The melted material impinges on the object, where it coalesces and solidifies (6).

Plasma spraying techniques are advantageous because the substrate is kept at relatively low temperatures (about $100^{\circ} \mathrm{C}$ ) and all kinds of material can be used for coating. Moreover, the adhesion to the substrate is very good, and the coating permits patchy repair.

Hazards. Plasma spraying generates considerable noise, and the use of a direct-current arc results in ultraviolet radiation, ozone, and nitrous gases (6). The process room, therefore, requires exhaust ventilation, and the workers should be equipped with both acoustical and visual protection, as well as an air-line respirator (table 1).

\section{Powder metallurgy}

\section{General aspects}

Powder metallurgy is defined as the production of metal powders and their utilization for the manufacture of massive materials. Powder metallurgy techniques are used to produce a wide variety of products consisting of metals, alloys, or metals in combination with nonmetals, as for instance cermets. Powder metallurgy techniques are both economically and technically advantageous. They are well suited for mass production, and it is possible to produce objects that cannot be made with conventional techniques. Furthermore, the powder metallurgy process is generally "clean" as compared with ordinary metal casting (9).

Metal powders can be produced by several different methods (eg, reduction from metal oxides and atomization of molten metal by air or water jet and by electrolytic deposition). The production of powders also involves milling and screening to obtain powders with the required particle dimension.

The particles in the powders are generally in the size range of $100-200 \mu \mathrm{m}$, but fine particles $(1-10 \mu \mathrm{m})$ and ultrafine particles $(1-100 \mathrm{~nm})$ are also used.

For producing massive objects, the metal powders are mixed, and a lubricant is added (metal stearate, paraffin, molybdenum disulfide). The mixture is then passed into a die where it is consolidated by the application of heat and/or pressure (cold isostatic pressing 
or hot isostatic pressing). Afterwards, the compact object is sintered at temperatures ranging from $760^{\circ} \mathrm{C}$ to $2400^{\circ} \mathrm{C}$ depending on the material (figure 3). In another variation of the method, injection molding, very fine powders are mixed with a thermoplastic resin, and the mixture is injected into the replica. The resin may be extracted with solvents before the sintering, or it is simply pyrolyzed during the sintering. The finishing treatments of the powder metallurgy products include grinding and surface treatment such as plating or coloring (9).

In addition to the more common metals (iron, copper, aluminum, lead, tin, nickel, tungsten, cobalt, chromium) and their alloys, powder metallurgy techniques also make use of various rare earths (samarium, cerium, thorium) and molybdenum, vanadium, niobium, tantalum, titanium, and zirconium, especially as carbides. Objects which are produced by mixtures of a ceramic material (eg, chromium carbide, titanium carbide, titanium nitride, or a metal oxide) and metals (nickel-chromium, cobalt-chromium, nickelmolybdenum) are called cermets or metal-matrix composites, depending on the amount of metal in the product (10). In these products, the high-temperature resistance of the ceramics is combined with the highfracture resistance of the metals.

Hazards. The most important occupational hazard in powder metallurgy is probably exposure to dust (table 2). Airborne dust can develop during the production and mixing of the powders and during the grinding of the consolidated or sintered objects.

The powders used in powder metallurgy have a tremendously high surface area:volume ratio which increases properties such as explosiveness and toxicity. Furthermore, the use of fine and ultrafine powders increases the risk of inhalation. Consequently, effective dust control is of paramount importance as a preventive measure against accidents and work-related dis- eases. Very fine powders should, as far as possible, be handled in closed systems, and operations that create airborne dust should be avoided.

The toxicology of many of the metals used in powder metallurgy is well known (eg, lead, cadmium, beryllium, cobalt, nickel) and the health hazards associated with the handling of these metals are generally acknowledged (11). Exposure to chromium and nickel, which are strong sensitizers, increases the risk of occupational dermatitis, and cobalt dust plays a central role in the development of asthma and hard metal disease among workers in the cemented carbide industry $(12,13,14)$.

The biological effects of oxides appear to be well known (see the section Advanced Technical Ceramics), whereas information on the carbides is very limited. Chromium carbide has been reported to produce thickening of the alveolar septa in rats after intratracheal instillation (15), whereas tantalum carbide, tungsten carbide, and titanium carbide are considered inert (16). However, due to the lack of long-term inhalation experiments with animals, it is not possible to decide whether or not the different types of carbide dust constitute an occupational hazard.

\section{Advanced technical ceramics}

\section{General aspects}

Ceramics are defined as inorganic, nonmetallic materials that are processed at high temperatures. While traditional ceramics (pottery, tiles, etc) are made from naturally occurring minerals (clay, silica, feldspar), advanced technical ceramics encompass a wide range of compounds such as carbides, nitrides, oxides, and titanates. More than 450 compounds are used in the manufacture of ceramic products (17), and only a fraction of these compounds are listed in the appendix.

Advanced technical ceramics are particularly known for their extreme heat resistance and hardness, which

Table 2. Occupational hazards associated with powder metallurgy, advanced technical ceramics, and fiber-reinforced plastics.

\begin{tabular}{|c|c|c|}
\hline Technique & Hazard & Preventive measure \\
\hline Powder metallurgy & $\begin{array}{l}\text { Respirable dust } \\
\text { Sensitizing metals (cobalt, nickel) } \\
\text { (asthma, dermatitis) } \\
\text { Toxic metals (eg, cadmium, lead) } \\
\text { Pyrophoric metals (fire, dust explosions) } \\
\text { Compact presses }\end{array}$ & $\begin{array}{l}\text { Shielding, exhaust ventilation, } \\
\text { protection masks } \\
\text { Gloves, exhaust ventilation } \\
\text { Protection masks, exhaust ventilation } \\
\text { Exhaust ventilation, avoidance of } \\
\text { flames, protection against sparks } \\
\text { Shielding }\end{array}$ \\
\hline Advanced technical ceramics & $\begin{array}{l}\text { Respirable dust (pneumoconiosis, fibrogenic } \\
\text { material, carcinogenic agent) } \\
\text { Toxic elements (lead in different compounds) } \\
\text { Irritative compounds (cadmium oxide, } \\
\text { magnesium oxide) }\end{array}$ & $\begin{array}{l}\text { Protective masks, exhaust ventilation } \\
\text { Protective masks, exhaust ventilation } \\
\text { Protective masks, exhaust ventilation }\end{array}$ \\
\hline Fiber-reinforced plastics & $\begin{array}{l}\text { Toxic solvents (eg, neurotoxic, carcinogenic, } \\
\text { irritating agents) } \\
\text { Sensitizing compounds } \\
\text { Dust from machining (fibers, matrix) } \\
\text { Flammable solvents }\end{array}$ & $\begin{array}{l}\text { Shielding, exhaust ventilation } \\
\text { Exhaust ventilation, gloves } \\
\text { Exhaust ventilation, protection masks, } \\
\text { gloves } \\
\text { Avoidance of flames }\end{array}$ \\
\hline
\end{tabular}




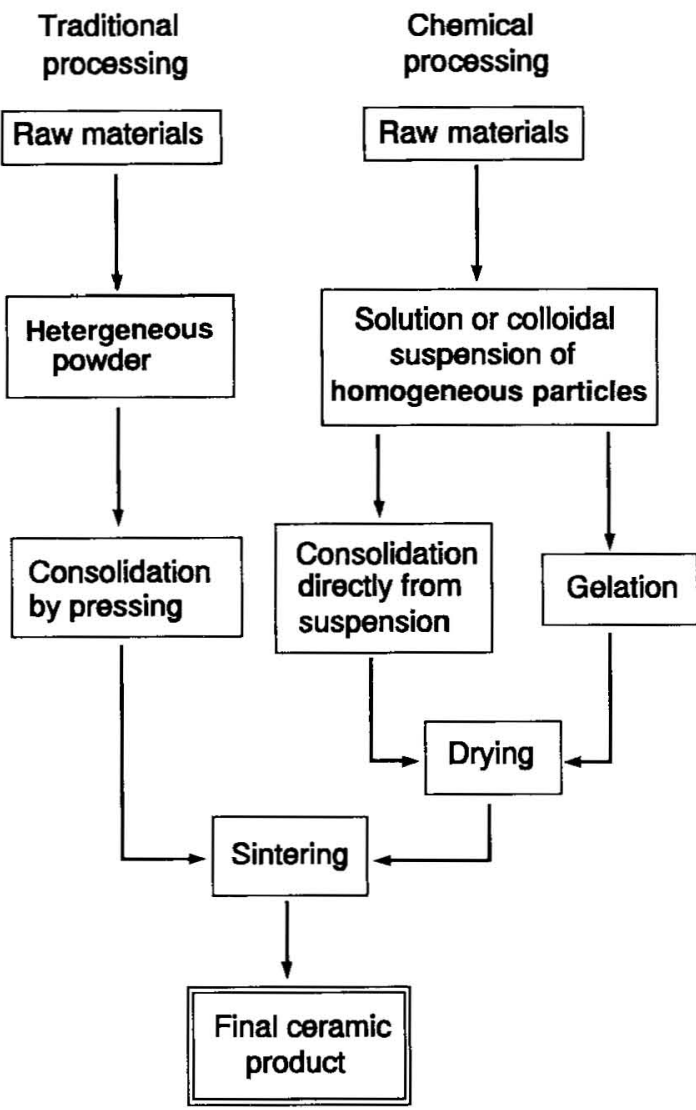

Figure 4. Main steps of the traditional and chemical way of processing ceramic powders. Adapted from reference 21 .

make them attractive as engineering materials. These structural ceramics are increasingly used as components in engines, where they replace high-performance metals (eg, in exhaust manifolds, piston caps, turbocharger blades, etc). Other types of ceramics have unique electrical or optical properties, and some are used as surgical implants (bioceramics). Electrical ceramics include passive materials such as alumina and silicon dioxide, but also more active compounds which are used in pressure transducers and solar cells $(10,18,19,20)$.

Ceramic powders, which constitute the raw materials, are produced by grounding or milling or by chemical methods (gel-sol processing), in which the particles are formed by polymerization. Gel-sol processing results in homogeneous particles with sizes in the submicron range $(10,21)$.

The overall process in the manufacture of ceramic products resembles that of powder metallurgy. The ceramic powders are mixed and consolidated into compacts by dry pressing followed by sintering (figure 4). Compacts may also be produced from colloidal suspensions of the powders ("slurries") by slip casting, in which the liquid is absorbed by the porous mold before the sintering (21).
During sintering, the ceramic particles coalesce, and the density of the product increases. Due to their extreme hardness, ceramics are generally not subjected to further treatment after being sintered. However, the surface of the object may be polished if required, and smaller items may be cut with lasers.

Electronic ceramics, which are generally used in smaller amounts, may be produced as thin films by techniques such as physical vapor deposition, ion beam sputtering, and chemical vapor deposition (22).

Many ceramic compounds are available as fibers or whiskers, which are used particularly for purposes of insulation (eg, furnace linings) and as reinforcing inclusions in resins, metals, and ceramics. Ceramic fibers can be classified into two groups, oxide fibers, which include alumina, zirconia, and chemically modified alumina-silica fibers, and nonoxide fibers such as silicon carbide, silicon nitride, and boron nitride. The diameter of the fibers range from $1 \mu \mathrm{m}$ to about $10 \mu \mathrm{m}$, but whiskers are usually somewhat thinner (10). The fibers are commercially available in bulk material or come as blankets or felts. Continuous fibers may even be twisted into yarns and woven into heat-resistant clothing (23).

\section{Hazards}

The most important health hazard in the manufacture of advanced technical ceramics is probably the inhalation of dust (table 2). The storing and mixing of ceramic materials in a dry, powdered form increases the risk for developing airborne dust that may be inhaled. The use of ceramic powders with particle size in the submicron range further increases the risk of inhalation. Protective measures should therefore include effective dust control, local exhaust ventilation, and the use of respirators during operations that are likely to create airborne dust.

Except for beryllium oxide, most of the compounds used in advanced technical ceramics have only limited acute toxicity, and titanium dioxide, zirconium silicate, and titanium carbide are considered biologically inert $(16,24,25,26)$. Inhalation of cerium oxide and tin dioxide has been reported to result in benign pneumoconiosis $(11,27)$, and nickel monoxide and beryllium oxide have the potential of inducing cancer (28). Furthermore, some of the compounds (eg, calcium oxide, cobalt oxide, zirconium oxide) may cause irritation or allergic reactions (29-31). More important, however, is that next to nothing is known about the biological effects of several of the compounds (eg, some nitrides, carbides, niobates, and titanates), and dust of these materials should be considered hazardous until proved otherwise.

Information on the toxicology of ceramic fibers appears to be very limited (32), except for those made of glass and asbestos. Fibers with diameters below $3 \mu \mathrm{m}$ are classified as respirable (33), and long and thin durable fibers (diameter $<0.25 \mu \mathrm{m}$, length $>8 \mu \mathrm{m}$ ) 
appear to be carcinogenic (34). Very thin ceramic fibers or whiskers should accordingly be considered as potentially hazardous, as they might turn out to be carcinogenic. Recent animal experiments seem to confirm this possibility since it has been found that inhalation of kaolin-based ceramic fibers (diameter $1 \mu \mathrm{m}$, length $25 \mu \mathrm{m}$ ) produced pleural mesothelioma in 36 out of 102 animals (35). Furthermore, in vitro experiments have shown that silicon carbide whiskers are more cytotoxic than crocidolite fibers (36).

\section{Fiber-reinforced plastics}

\section{General aspects}

Fiber-reinforced plastics are composite materials consisting of fibers embedded in a matrix of plastic. Their products combine high strength with low density and can serve as substitutes for steel and other construction materials where weight is critical. These composite materials were originally developed for use in the aerospace industry, but, since more fiber types have become available commercially, fiber-reinforced plastics are now being used increasingly. In addition to the use in the aerospace industry, fiber-reinforced plastics occur in land vehicles, boats, sporting goods, and prostheses (37).

The most commonly used fibers are made of glass, carbon, boron, or aramid. The fibers are embedded in a matrix of a thermosetting resin (eg, polyester, epoxy) or a thermoplastic (eg, polyether etherketone, polyether imide), depending on the physical characteristics that are needed. The fiber and matrix are often combined in tapes (prepregs) containing about 60 (volume) $\%$ fibers and ranging in width from about $3 \mathrm{~mm}$ to $1 \mathrm{~m}$. Prepregs may then be stacked together to form a laminate component. Fiber-reinforced plastics can also be produced by a process called filament winding, which is particularly useful for cylindrical objects.

Cured objects made of fiber-reinforced plastics can require machining such as drilling, sawing, or grinding before the final product is obtained. In these processes, large amounts of dust can develop.

\section{Hazards}

The occupational hazards associated with the production of fiber-reinforced plastics are those which apply to the plastics industry in general. In other words, there can be exposure to many solvents and liquids that may be neurotoxic, carcinogenic, irritating, or sensitizing (table 2). Although these problems are important and serious, the present paper is restricted to the toxicology of the fibers and the possible health effects of handling fibers and machining the cured fiber-reinforced plastics objects.
Carbon fibers. There are several papers concerning the toxicological effects or health implications of exposure to dust from carbon fibers. Inhalation experiments with animals (rats and guinea pigs) indicate that carbon fiber dust does not produce systemic toxicity or pathological changes in the lungs $(38,39)$. However, a Soviet animal study indicates that dust from carbon fibers produces slight pulmonary fibrosis and irritation of the respiratory tract (40). Medical examination and respiratory symptom questionnaires of workers engaged in carbon fiber production have revealed no adverse effects on the lungs (41).

Carbon fibers tend to break laterally rather than longitudinally when milled $(38,41)$. Fibrous dust consisting of long and thin fibers, which are generally believed to be carcinogenic (34), is therefore not likely to develop. However, it has been reported that the sawing and drilling of carbon/epoxy composites produce free fibers, some of which show evidence of longitudinal cleavage (42).

Taken together, these studies indicate that carbon fibers present little or no chronic health risk during manufacture and use. Dust from carbon fibers may, however, present an indirect fire hazard, since it can cause short-circuiting in electrical installations (43).

Aramid fibers. Aramid fibers do not produce allergic reactions on skin contact, and inhalation experiments with rats show only minimal tissue reaction in response to the dust. In addition there is only little or no collagen deposition in the lungs $(44,45)$. Furthermore, in traperitoneal injections of dust from aramid fibers do not appear to increase the rate of tumors in rats (46).

Boron fibers. In a literature search, no papers related to the toxicology of this fiber type were identified.

Glass fibers. Since glass fibers can hardly be considered a new material (they have been in use for more than 50 years), the occupational hazards will be outlined only for comparative purposes. Skin irritations and itching are common complaints of workers exposed to dust either from handling the fibers or from machining plastics reinforced with glass fibers (47). Glass fibers may also produce a transient irritation of the mucous membranes of the eyes, nose, and throat (48), but adverse effects such as lung fibrosis, lung cancer, or mesothelioma have not been observed either in epidemiologic studies or in inhalation experiments with animals (49). Furthermore, the latest critical review of epidemiologic data shows that the standard mortality rate for lung cancer is not significantly increased by exposure to fine glass fibers $(50)$. In animal experiments it has been found that very thin glass fibers (diameter $<1.5 \mu \mathrm{m}$ ) are highly carcinogenic after intrapleural implantation (51). However, these ex- 
periments are unrelated to occupational exposure. Glass fibers used for reinforced plastics have diameters of $9-24 \mu \mathrm{m}$, and an examination of dust shows that longitudinal splitting of the fibers does not occur during grinding (52).

Matrix dust. The sawing and drilling of cured composites produce dust in the respirable size range, and it appears that several chemical agents, some of which have a sensitizing capacity, are released from the dust $(43,53)$. Although exposure to chemicals degassing from the dust occurs on a minor scale compared with the prepreging and lay-up processes, the hazard should not be ignored. In fact, there are reports of allergic contact dermatitis due to trace amounts of epoxy in the finished product (43). The intratracheal instillation of dust from carbon fiber epoxy composites in rats showed that some fabrics were inert, while others produced slight fibrotic changes in the lungs (53). This result has been supported by in vitro experiments with rabbit alveolar macrophages (54). However, it has not been established which component of the fiber-reinforced plastics (fiber, matrix, or additive) is responsible for the toxic effect.

To minimize exposure to fiber fragments produced in the machining of cured fiber-reinforced plastics, local exhaust ventilation should be applied. There is evidence that the occupational exposure limit for dust is frequently exceeded during the grinding of fiberreinforced plastics, even though the machines are equipped with an exhaust device (52). Therefore, it is recommended that workers wear gloves and respiratory protection masks during grinding.

\section{Acknowledgments}

This work is part of a project supported by the Nordic Council of Ministers. We gratefully acknowledge the help and advice of the steering group, which consisted of Dr S Krantz (Stockholm), Dr D Ryberg (Oslo), Dr P Wilhardt (Copenhagen), and Dr A Zitting (Helsinki).

\section{References}

1. Leibowitz AJ. The industrial hygiene impact of new materials and technology. Am Ind Hyg Assoc J 1990; 51:A350-3.

2. National Institute of Occupational Safety and Health (NIOSH). Registry of toxic effects of chemical substances (RTECS). Cincinnati, OH: NIOSH, 1990.

3. Straede CA. Practical applications of ion implantation for tribological modification of surfaces. Wear 1989; 130:113-22.

4. Ungers LJ, Jones JH. Industrial hygiene and control technology assessment of ion implantation operations. Am Ind Hyg Assoc J 1986;47:607-14.

5. Lee SM. Film deposition techniques. In: Kirk RE, Othmer DF, Grayson M, Eckroth D, ed. Encyclopedia of chemical technology; vol 10. 3rd ed. New York, NY: John Wiley and Sons, 1980:247-83.
6. Bunshah RF. Refractory coatings. In: Kirk RE, Othmer DF, Grayson M, Eckroth D, ed. Encyclopedia of chemical technology; vol 20. 3rd ed. New York, NY: John Wiley and Sons, 1982:38-64.

7. Kieffer R, Benesovsky F. Carbides. In: Kirk RE, Othmer DF, Grayson M, Eckroth D, ed. Encyclopedia of chemical technology; vol 4. 3rd ed. New York, NY: John Wiley and Sons, 1978:476-89.

8. Benesovsky F, Kieffer R, Ettmayer P. Nitrides. In: Kirk RE, Othmer DF, Grayson M, Eckroth D, ed. Encyclopedia of chemical technology; vol 15. 3rd ed. New York, NY: John Wiley and Sons, 1981:871-81.

9. Roll KH. Powder metallurgy. In: Kirk RE, Othmer DF, Grayson M, Eckroth D, ed. Encyclopedia of chemical technology; vol 19. 3rd ed. New York, NY: John Wiley and Sons, 1982:28-62.

10. Sanders HJ. High-tech ceramics. Chem Eng News 1984;62(28):26-40.

11. Kipling MD. Health hazards and powder metallurgy. J Soc Occup Med 1976;26:81-4.

12. Balmes JR. Respiratory effects of hard-metal dust exposure. In: Rosenstock L, ed. Occupational pulmonary disease. Philadelphia, PA: Hanley and Belfus, 1987: 327-44.

13. Scherrer M, Maillard J-M. Hartmetall-Pneumopathien. Schweiz Med Wochenschr 1982;112:198-207.

14. Coates ED Jr, Watson JHL. Diffuse interstitial lung disease in tungsten carbide workers. Ann Intern Med 1971; 75:709-16.

15. Brakhnova IT. Comparative evaluation of the influence exerted on the organism by borides and carbides of transient metals with due regard for their electron structure [in Russian]. Gig Tr Prof Zabol 1969;13(1):26-31.

16. Schiller E. Tierversuche zum Problem der HartmetallLunge. In: Thomas K, Einbrodt $\mathrm{HJ}$, ed. Grundfragen aus der Silikoseforschung; vol III. Bochum: Bergbau Berufsgenossenschaft, 1959:77-84.

17. Hamme JV. Ceramics, raw materials. In: Kirk RE, Othmer DF, Grayson M, Eckroth D, ed. Encyclopedia of chemical technology; vol 5. 3rd ed. New York, NY: John Wiley and Sons, 1979:237-53.

18. Bell J. The ceramic age dawns. New Sci 1984;1394: $10-2$.

19. Brook R, Riley F. Density means toughness. New Sci 1984;1394:13-6.

20. Gregory G. New materials refresh industry. New Sci 1984;1394: 20-2.

21. Ulrich DR. Chemical processing of ceramics. Chem Eng News 1990;68(1):28-40.

22. Sayer M, Sreenivas K. Ceramic thin films: fabrication and applications. Science 1990;247:1056-60.

23. Miller WC. Refractory fibers. In: Kirk RE, Othmer DF, Grayson M, Eckroth D, ed. Encyclopedia of chemical technology; vol 20. 3rd ed. New York, NY: John Wiley and Sons, 1982:65-77.

24. World Health Organization (WHO). Titanium. Geneva: WHO, 1982. (Environmental health criteria; no 24.)

25. Parkes WR. Occupational lung disorders. 2nd ed. London: Butterwords, 1982.

26. Harding HE. The toxicology of zircon: preliminary report. Br J Ind Med 1948;5:75-6.

27. Wolf AF. Occupational diseases of the lungs: part II. inhalation diseases due to inorganic dust. Ann Allergy 1975;35:87-92.

28. International Agency for Research on Cancer (IARC). Overall evaluations of carcinogenicity: an updating of IARC monographs volumes 1 to 42. Lyon: IARC, 1987. (IARC monographs on the evaluation of the carcinogenic risk of chemicals to humans; suppl 7.)

29. Wands RC. Alkaline materials. In: Clayton GF, Clayton FE, ed. Patty's industrial hygiene and toxicology; vol IIB. 3rd ed. New York, NY: Wiley and Sons, 1981: $3045-70$. 
30. Elinder CG, Friberg L. Cobalt. In: Friberg L, Nordberg GF, Vouk V, ed. Handbook on the toxicology of metals. 2nd ed. Amsterdam: Elsevier, 1986:.211-32.

31. Baler GR. Granulomas from topical zirconium in poison ivy dermatitis. Arch Dermatol 1965;91:145-8.

32. Gross P, Braun DC. Toxic and biomedical effects of fibers asbestos, talc, inorganic fibers, man-made vitreous fibers, and organic fibers. Park Ridge NJ: Noyes Publications, 1984.

33. Leineweber JP. Fiber toxicology. J Occup Med 1981; 23:431-4.

34. Stanton MF, Layard M, Tegeris A, Miller E, May M, Morgan E, Smith A. Relation of particle dimension to carcinogenicity in amphibole asbestoses and other fibrous materials. J Natl Cancer Res 1981;67:965-75.

35. Hesterberg TW, Mast R, McConnell EE, et al. Chronic inhalation toxicity of refractory ceramic fibers in Syrian hamsters. Presented at the NATO Advanced Research Workshop on Mechanisms in Fibre Carcinogenesis. Albuquerque, NM, 1990.

36. Johnson NF, Hoover MD, Cheng YS. The cytotoxicity of fibrous materials used in advanced ceramic composites. Presented at the NATO Advanced Research Workshop on Mechanisms in Fibre Carcinogenesis in Albuquerque, NM, 1990.

37. Davis J. Composites, high performance. In: Kirk RE, Othmer DF, Grayson M, Eckroth D, ed. Encyclopedia of chemical technology; suppl vol. 3rd ed. New York, NY: John Wiley and Sons, 1984:260-81.

38. Holt PF, Horne M. Dust from carbon fibre. Environ Res 1978;17:276-83.

39. Owen PE, Glaister JR, Ballantyne B, Clary JJ. Subchronic inhalation toxicology of carbon fibers. J Occup Med 1986;28:373-6.

40. Fedjakina RP. Biological effect of exposure to carbon fibre dust (experimental data). Gig Tr Prof Zabol 1984;3: $30-2$.

41. Jones HD, Jones TR, Lyle WH. Carbon fibre: results of a survey of process workers and their environment in a factory producing continuous filament. Ann Occup Hyg 1982;26:861-8.

42. Wagman J, Berger HR, Miller JL, Conner WD. Dusts and residues from machining and incinerating graphiteepoxy composites: a preliminary study. Environ Technol Lett 1982;3:465-78.
43. Kowalska M. Carbon fibre reinforced epoxy prepregs and composites - health risks aspects. SAMPE Q 1982; 13:13-9.

44. Reinhardt CF. Toxicology of aramid fibers. In: US Environmental Protection Agency. Proceedings of national work shop on substitutes for asbestos. Washington, DC: US Environmental Protection Agency, 1980:443-8.

45. Lee KP, Kelly DP, Kennedy GL Jr. Pulmonary response to inhaled Kevlar aramid synthetic fibers in rats. Toxicol Appl Physiol 1983;71:242-53.

46. Pott F, Ziem U, Reiffer F-J, Huth F, Ernst H, Mohr U. Carcinogenicity studies on fibres, metal compounds, and some other dusts in rats. Exp Pathol 1987;32: 129-52.

47. Key MM, Konzen JL, Devitt GE. Polyester resins. In: Parmeggiani L, ed. Encyclopedia of occupational health and safety. 3rd ed. Geneva: International Labour Organization, 1983:1761-2.

48. Hill GW. Fibres, man-made glass and mineral. In: Parmeggiani L, ed. Encyclopedia of occupational health and safety. 3rd ed. Geneva: International Labour Organization, 1983:852-5.

49. Gross P. Man-made vitreous fibers: an overview of studies on their biological effect. Am Ind Hyg Assoc J 1986;47:717-23.

50. Miettinen OS, Rossiter CE. Man-made mineral fibers and lung cancer: epidemiologic evidence regarding the causal hypothesis. Scand J Work Environ Health 1990; $16: 221-31$

51. Stanton MF, Layard M, Tegeris A, Miller E, May M, Kent E. Carcinogenicity of fibrous glass: pleural response in the rat in relation to fiber dimension. J Natl Cancer Inst $1977 ; 58: 587-603$.

52. Antonsson A-B. Runmark S. Airborne fibrous glass and dust originating from worked reinforced plastics. Am Ind Hyg Assoc J 1987:48:684-7.

53. Luchtel DL, Martin TR, Boatman ES. Characterization of dusts from machining of fiber-epoxy composites and biological responses to respirable fractions. In: Felton $\mathrm{DL}$, ed. Biological interaction of inhaled mineral fibers and cigarette smoke. Columbus, $\mathrm{OH}$ : Battelle Memorial Institute, 1989:291-312.

54. Martin TR, Meyer SW, Luchtel DR. An evaluation of the toxicity of carbon fiber composites for lung cells in vitro and in vivo. Environ Res 1989;49:246-61.

\section{Appendix}

\section{Materials used in metal surface treatment, powder metallurgy, advanced technical ceramics and fiber-reinforced plastics}

The following table lists materials used in metal surface treatment, powder metallurgy, advanced technical ceramics, and fiber-reinforced plastics. In the last column + indicates the existence of toxicological data and - indicates that there is no or only very little information on the toxicity. Note: The list is not intended to be exhaustive. (The compounds have been identified from various handbooks, information booklets, and from research descriptions from technology centers.)

\begin{tabular}{|c|c|c|c|c|c|c|}
\hline Compound & $\begin{array}{l}\text { Formula or } \\
\text { abbreviation }\end{array}$ & $\begin{array}{c}\text { Metal } \\
\text { surface } \\
\text { treatment }\end{array}$ & $\begin{array}{l}\text { Powder } \\
\text { metallurgy }\end{array}$ & $\begin{array}{l}\text { Advanced } \\
\text { technical } \\
\text { ceramics }\end{array}$ & $\begin{array}{l}\text { Fiber- } \\
\text { reinforced } \\
\text { plastics }\end{array}$ & $\begin{array}{l}\text { Toxi- } \\
\text { cological } \\
\text { data }\end{array}$ \\
\hline
\end{tabular}

Metals and alloys

Aluminum

Aluminum-magnesium

Al

Al-Mg

$+$

$+$

(continued) 


\begin{tabular}{|c|c|c|c|c|c|c|}
\hline Compound & $\begin{array}{l}\text { Formula or } \\
\text { abbreviation }\end{array}$ & $\begin{array}{c}\text { Metal } \\
\text { surface } \\
\text { treatment }\end{array}$ & $\begin{array}{l}\text { Powder } \\
\text { metallurgy }\end{array}$ & $\begin{array}{l}\text { Advanced } \\
\text { technical } \\
\text { ceramics }\end{array}$ & $\begin{array}{l}\text { Fiber- } \\
\text { reinforced } \\
\text { plastics }\end{array}$ & $\begin{array}{l}\text { Toxi- } \\
\text { cological } \\
\text { data }\end{array}$ \\
\hline
\end{tabular}

Cadmium

Chromium

$\mathrm{Cd}$

Chromium-molybdenum

$\mathrm{Cr}$

Cobalt

Cr-Mo

Cobalt-tin

Co-sn

Cobalt-tungsten

Co-Sn

Copper-tin

Copper

Gold

Indium

Iron-nickel

Iron-zinc

Lead

Lead-tin

Molybdenum

Nickel

Cu-Sn

$\mathrm{Cu}$

$\mathrm{Au}$

In

$\mathrm{Fe}-\mathrm{Ni}$
$\mathrm{Fe}-\mathrm{Zn}$

$\mathrm{Pb}$

$\mathrm{Pb}-\mathrm{Sn}$

Mo

$\mathrm{Ni}$

Nickel-aluminum

Nickel-cadmium

Nickel-chromium

$\mathrm{Ni}-\mathrm{Al}$

$\mathrm{Ni}-\mathrm{Cd}$

Nickel-graphite

$\mathrm{Ni}-\mathrm{Cr}$

$\mathrm{Ni}-\mathrm{C}$

Nickel-palladium Ni-Pd

Nickel-tin

Nickel-phosphorus

$\mathrm{Ni}-\mathrm{Sn}$

Ni-P

Nickel-tungsten Ni-W

Nickel-zinc

$\mathrm{Ni}-\mathrm{Zn}$

Silver

Tantalum

$\mathrm{Ag}$

Tin

Titanium

Tungsten

Yttrium

Zirconium

$+$

Boron-containing substances

Boron

Ferri boride

Lanthanum boride

Niobium boride

Tantalaum boride

Titanium boride

Tungsten boride

Zirconium boride

Carbides

Boron carbide

Calcium carbide

Chromium carbide

Chromium carbide

Iron carbide

Molybdenum carbide

Niobium carbide

Silicon carbide

Tantalum carbide

Titanium carbide

Tungsten carbide

Tungsten carbide-cobalt

Vanadium carbide

Zirconium carbide

Nitrides

Aluminum nitride

Boron nitride

Chromium nitride

Lithium nitride

Silicon nitride

Tantalum nitride

Titanium nitride

Zirconium nitride

FeB

$\mathrm{LaB}_{6}$

$\mathrm{NbB}$

$\mathrm{TaB}_{2}$

$\mathrm{TiB}_{2}$

WB

$\mathrm{ZrB}_{2}$

$+$

Ti

Yr

$\mathrm{BC}$

$\mathrm{CaC}_{3} \mathrm{C}_{2}, \mathrm{CrC}$

$\mathrm{Cr}_{7} \mathrm{C}_{3}$

$\mathrm{FeC}$

$\mathrm{Mo}_{2} \mathrm{C}$

$\mathrm{NbC}$

$\mathrm{SiC}$

$\mathrm{TaC}$

TiC

wC

WC-Co

vC

$\mathrm{ZrC}$

AIN

$\mathrm{BN}, \mathrm{Cr}_{2} \mathrm{~N}$

$\mathrm{Li}_{3} \mathrm{~N}$

$\mathrm{Si}_{3} \mathrm{~N}_{4}$

TaN

TiN

$\mathrm{ZrN}$

Oxides

Aluminum oxide

Beryllium oxide

Lead oxide

Calcium oxide

Cerium oxide

$\mathrm{Al}_{2} \mathrm{O}_{3}$

$\mathrm{BeO}$

$\mathrm{PbO}$

Cao

$\mathrm{CeO}_{2}$

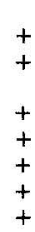

$+$

+
+
+

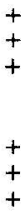




\begin{tabular}{|c|c|c|c|c|c|c|}
\hline Compound & $\begin{array}{l}\text { Formula or } \\
\text { abbreviation }\end{array}$ & $\begin{array}{c}\text { Metal } \\
\text { surface } \\
\text { treatment }\end{array}$ & $\begin{array}{l}\text { Powder } \\
\text { metallurgy }\end{array}$ & $\begin{array}{l}\text { Advanced } \\
\text { technical } \\
\text { ceramics }\end{array}$ & $\begin{array}{l}\text { Fiber- } \\
\text { reinforced } \\
\text { plastics }\end{array}$ & $\begin{array}{l}\text { Toxi- } \\
\text { cological } \\
\text { data }\end{array}$ \\
\hline $\begin{array}{l}\text { Chromium oxide } \\
\text { Cobalt oxide } \\
\text { Magnesium oxide } \\
\text { Manganese oxide } \\
\text { Nickel monoxide } \\
\text { Niobium pentoxide } \\
\text { Silicon dioxide } \\
\text { Tantalum oxide } \\
\text { Tin dioxide } \\
\text { Titanium dioxide } \\
\text { Tungsten oxide } \\
\text { Vanadium oxide } \\
\text { Yttrium oxide } \\
\text { Zinc oxide } \\
\text { Zirconium oxide }\end{array}$ & $\begin{array}{l}\mathrm{Cr}_{2} \mathrm{O}_{3}, \mathrm{CrO}_{2} \\
\mathrm{CoO} \\
\mathrm{MgO} \\
\mathrm{MnO} \\
\mathrm{NiO} \\
\mathrm{Nb}_{2} \mathrm{O}_{5} \\
\mathrm{SiO}_{2} \\
\mathrm{Ta}_{2} \mathrm{O}_{5} \\
\mathrm{SnO}_{2} \\
\mathrm{TiO}_{2} \\
\mathrm{WO}_{3} \\
\mathrm{VO}_{2}, \mathrm{~V}_{2} \mathrm{O}_{3} \\
\mathrm{Y}_{2} \mathrm{O}_{3} \\
\mathrm{ZnO} \\
\mathrm{ZrO}_{2}\end{array}$ & + & $\begin{array}{l}+ \\
+\end{array}$ & $\begin{array}{l}+ \\
+ \\
+ \\
+ \\
+ \\
+ \\
+ \\
+ \\
+ \\
+\end{array}$ & & $\begin{array}{l}+ \\
+ \\
+ \\
+ \\
+ \\
+ \\
+ \\
+ \\
+ \\
+ \\
+ \\
+ \\
+ \\
+ \\
+\end{array}$ \\
\hline \multicolumn{7}{|l|}{ Fibers/whiskers } \\
\hline $\begin{array}{l}\text { Aluminum oxide } \\
\left.\text { Aramid (Kevlar }{ }^{(}\right) \\
\text {Beryllium oxide } \\
\text { Boron/boron carbide } \\
\text { Carbon } \\
\text { Glass } \\
\text { Iron carbide } \\
\text { Ceramic fibers }\left(\mathrm{Nextel}^{\left({ }^{\oplus}\right.}\right) \\
\text { Potassium octatitanate } \\
\text { Potassium titanate } \\
\text { Silicon carbide } \\
\text { Zirconium oxide }\end{array}$ & $\begin{array}{l}\mathrm{Al}_{2} \mathrm{O}_{3} \\
\because \\
\mathrm{BeO} \\
\mathrm{B} / \mathrm{BC} \\
\mathrm{C} \\
\mathrm{FeC} \\
\cdots \\
\cdots \\
\cdots \\
\mathrm{SiC} \\
\mathrm{ZrO}_{2}\end{array}$ & & + & + & $\begin{array}{l}+ \\
+ \\
+ \\
+\end{array}$ & $\begin{array}{l}+ \\
+ \\
- \\
+ \\
+ \\
+ \\
+ \\
+ \\
+ \\
+ \\
+ \\
+\end{array}$ \\
\hline \multicolumn{7}{|l|}{ Polymers } \\
\hline $\begin{array}{l}\text { Epoxy } \\
\text { Nylon block copolymer } \\
\text { Polyamide } \\
\text { Polybutylene terephthalate } \\
\text { Polyether etherketone } \\
\text { Polyether imide } \\
\text { Polyether sulfone } \\
\text { Polyphenylene oxide } \\
\text { Polyethylene terephthalate } \\
\text { Polyphenylene sulfide } \\
\text { Polypropylene } \\
\text { Teflon }\end{array}$ & $\begin{array}{l}\text { PA } \\
\text { PABT } \\
\text { PEEK } \\
\text { PEI } \\
\text { PES } \\
\text { PPO } \\
\text { PETP } \\
\text { PPS } \\
\text { PP } \\
\text { PTFE }\end{array}$ & + & & & $\begin{array}{l}+ \\
+ \\
+ \\
+ \\
+ \\
+ \\
+ \\
+ \\
+ \\
+ \\
+\end{array}$ & $\begin{array}{l}+ \\
+ \\
+ \\
- \\
- \\
+ \\
+ \\
+ \\
+ \\
+ \\
+\end{array}$ \\
\hline \multicolumn{7}{|l|}{ Miscellaneous } \\
\hline $\begin{array}{l}\text { Barium titanate } \\
\text { Boron trichloride } \\
\text { Cadmium sulfide } \\
\text { Calcium fluoride } \\
\text { Carbon } \\
\text { Chromium dioxychloride } \\
\text { Copper selenide } \\
\text { Ferrite } \\
\text { Ferrite } \\
\text { Gallium arsenide } \\
\text { Krypton } \\
\text { Lead titanate } \\
\text { Lead-zirconium titanate } \\
\text { Lithium niobate } \\
\text { Lithium tantalate } \\
\text { Magnesium fluoride } \\
\text { Molybdenum disulfide } \\
\text { Molybdenum selenide } \\
\text { Molybdenum silicon } \\
\text { Nitrogen } \\
\text { Phosphorus } \\
\text { Titanium tetrachloride } \\
\text { Tungsten selenide } \\
\text { Vanadium tetrachloride } \\
\text { Zirconium fluoride } \\
\text { Zirconium silicate }\end{array}$ & $\begin{array}{l}\mathrm{BaTiO}_{3} \\
\mathrm{BCl}_{3} \\
\mathrm{CdS} \\
\mathrm{CaF} \\
\mathrm{C} \\
\mathrm{CrO}_{2} \mathrm{Cl}_{2} \\
\mathrm{CuSe}_{2} \mathrm{Cu}_{2} \mathrm{Se} \\
\left(\mathrm{Zn}, \mathrm{M}^{2} \mathrm{Fe}_{2} \mathrm{O}_{4}\right. \\
\mathrm{M} \mathrm{Fe}{ }_{12} \mathrm{O}_{19} \\
\mathrm{GaAs} \\
\mathrm{Kr} \\
\mathrm{PbTiO}_{3} \\
\left(\mathrm{~Pb}_{3} \mathrm{Zr}_{\mathrm{TiO}}\right. \\
\mathrm{LiNbO}_{3} \\
\mathrm{LiTaO}_{3} \\
\mathrm{MgF}_{2} \\
\mathrm{MoS}_{2} \\
\mathrm{MoSe}_{2} \\
\mathrm{MoSi}_{2} \\
\mathrm{~N} \\
\mathrm{P}_{2} \\
\mathrm{TiCl}_{4} \\
\mathrm{WSe}_{2} \\
\mathrm{VCl}_{4} \\
\mathrm{ZrF}_{2} \\
\mathrm{ZrSiO}_{4}\end{array}$ & $\begin{array}{l}+ \\
+ \\
+ \\
+\end{array}$ & + & $\begin{array}{l}+ \\
+ \\
+ \\
+ \\
+ \\
+ \\
+ \\
+ \\
+ \\
+\end{array}$ & . & $\begin{array}{l}- \\
+ \\
+ \\
+ \\
+ \\
+ \\
+ \\
+ \\
+ \\
+ \\
+ \\
+ \\
+ \\
+ \\
+ \\
+ \\
- \\
- \\
+ \\
+ \\
+ \\
+ \\
+ \\
+ \\
+\end{array}$ \\
\hline
\end{tabular}

Received for publication: 8 March 1991 